\title{
ZBTB38 wt Allele
}

National Cancer Institute

\section{Source}

National Cancer Institute. ZBTB38 wt Allele. NCI Thesaurus. Code C99621.

Human ZBT B38 wild-type allele is located in the vicinity of 3q23 and is approximately 126 $\mathrm{kb}$ in length. This allele, which encodes zinc finger and BTB domain-containing protein 38, is involved in the positive regulation of transcription. 